\title{
PCR Amplification of SRY-related Gene Sequences Reveals Evolutionary Conservation of the SRY-box Motif
}

\author{
Anne-Marie Coriat, ${ }^{1}$ Ulrike Müller, ${ }^{2}$ Jenny L. Harry, ${ }^{3}$ Dafe Uwanogho, ${ }^{1}$ and Paul T. Sharpe ${ }^{1}$
}

\begin{abstract}
${ }^{1}$ Molecular Embryology Laboratory, Department of Cell and Structural Biology, University of Manchester, M13 9PT UK; ${ }^{2}$ Institut für Molekularbiologie I, Universität Zürich, Hönggerberg, CH 8093, Zürich, Switzerland; ${ }^{3}$ Department of Zoology, University of Melbourne, Victoria 3052, Australia
\end{abstract}

\begin{abstract}
SRY (sex-determining region of the $Y$ chromosome) has recently been identified as a key regulatory gene in mammalian sex determination. The open reading frame of this gene contains an 80-amino-acid motif, the SRY-box, which shares a high degree of homology with a DNA-binding domain found in the high-mobilitygroup (HMG) proteins HMG1 and HMC2. The SRY box motif is highly conserved in several sequence-specific DNA-binding proteins that are known to act as transcription factors. Here we describe the use of degenerate PCR primers to identify SRY-related sequences containing the SRYbox motif from the genomic DNA of a variety of species. The results of this study suggest that in a diverse array of species SRY-related genes may serve as transcription factors that regulate a variety of developmental pathways, including sex determination.
\end{abstract}

n mammals, the male phenotype is determined by the expression of a testisdetermining factor (TDF) found on the $Y$ chromosome. Recently, a gene was discovered within the sex-determining region of the $\mathrm{Y}$ chromosome in mice (Sry) and humans (SRY) that is expressed at the onset of testicular differentiation. ${ }^{(1)}$ There is now substantial experimental evidence to support the correlation of $S R Y$ with TDF. ${ }^{(2-4)}$ Furthermore, malespecific homologs to the human SRY gene have been detected in all eutherian mammals tested. ${ }^{(5)}$

Translation of the open reading frame of $S R Y$ produces a putative protein containing an 80-amino-acid motif that has strong homology to a DNA-binding domain (HMG-box) in the high-mobilitygroup (HMG) proteins, HMG1 and HMG 2 . $^{(5,6)}$ This region of homology is referred to as the $S R Y$-box, to distinguish it from the nonsequence-specific DNAbinding HMG-box proteins. A diverse array of proteins containing this $S R Y$-box motif have been shown to have well-defined functions including: (1) Mc and mat-1, the cell-specialization regulators of the fission yeast Schizosaccaromyces pombe $^{(7)}$ and Neurospora crassa, ${ }^{(8)}$ respectively.; (2) SteII, a yeast protein from $S$. pombe that regulates sexual development $^{(9)}$; (3) cell differentiation factors TCF1 and TCF1a, human T-cell-specific transcription factors, ${ }^{(10)}$ and LEF1 a human lymphoid-specific transcription factor $^{(11)}$; (4) hUBF (human upstream binding factor), a general transcription factor for RNA polymerase I activity ${ }^{(12)}$; and (5) mouse protein IRE-ABP, which specifically binds the insulin response element $A{ }^{(13)}$

In addition, four other genes related to $S R Y$, Sox-1 to -4 , have been identified in the mouse and mapped to autosomal sites. ${ }^{(14)}$ These $S R Y$-related genes contain the conserved $S R Y$-box, but differ from the male-specific $S R Y$-box domain at several critical amino acid sites. ${ }^{(14)}$ The functions of Sox 1-4 are unknown, although expression patterns of these genes suggest a role in neuronal development.

Studies of the DNA-binding ability of the eukaryotic transcription factors have shown that the $S R Y$-box is itself a sequence-specifc DNA-binding motif ${ }^{(11,13,15,16)}$ and that the amino-terminal region of the box contains residues critical for DNA recognition. ${ }^{(16)}$ It is evident that the male-specific $S r y / S R Y$ gene products constitute an important class of HMG-like proteins whose function in sex determination is dependent upon the DNA-binding ability of the $S R Y$-box. Furthermore, the conservation of this DNA-binding domain in a number of $S R Y$-related genes suggests that a similar genetic mechanism may control a variety of developmental processes, including sex determination.

Identification of a key regulatory gene in mammalian sex determination provides an opportunity to investigate the evolution of this developmental pathway, using species with either chromosomal (Drosophila and chicken) or temperature-dependent (alligators and geckos) sex determination. Here we describe the use of degenerate PCR primers 
to amplify a family of $S R Y$-box-containing sequences from these species. Identification and characterization of this gene family will provide information concerning their evolutionary conservation and, ultimately, their functional homologies.

\section{MATERIALS AND METHODS}

Genomic DNA was prepared using whole body tissue from adult alligator, gecko, and Drosophila ${ }^{(17)}$ and whole blood from chicken. ${ }^{(18)}$ Three degenerate oligonucleotide primers [RG4-L, 5'-GAATTCGGTCAAGCGACCCATGAA(C/T)GCNTT3'; RG5-L, 5'-AAGCTTAGGTCGGTACTT(G/A)TA(G/A)T(C/T)NGG(A/G)TA-3'; 8S, 5'-AAGCTTATGGCCC(A/T)GGA(G/A)AACCCCAAGATG-3'] directed against conserved regions of the $S R Y$-box of human, mouse, and rabbit $S R Y$ and $S r y$-related mouse autosomal genes, were synthesized for PCR amplification and cloning of $S R Y$-related sequences. Nucleotides in parentheses indicate partial degeneracy and an $\mathrm{N}$ signifies total degeneracy. The primers RG4-L and RG5-L were adapted from those used to clone $S R Y$-related sequences from the lesser black-backed gull. $^{(19)}$ Primer $8 \mathrm{~S}$ was designed specifically to amplify sequences containing the amino acid motif $\mathrm{MA}(\mathrm{Q} / \mathrm{L}) \mathrm{EN}$, present in mouse Sry-related genes expressed in the developing nervous system. (20)

PCR reactions were performed in a final volume of $100 \mu \mathrm{l}$ containing $50 \mathrm{~mm}$ $\mathrm{KCl}, 10 \mathrm{~mm}$ Tris. $\mathrm{HCl}$ (pH 9.0), $1.5 \mathrm{~mm}$ $\mathrm{MgCl}_{2}, \quad 0.01 \%$ gelatin, $0.1 \%$ Triton

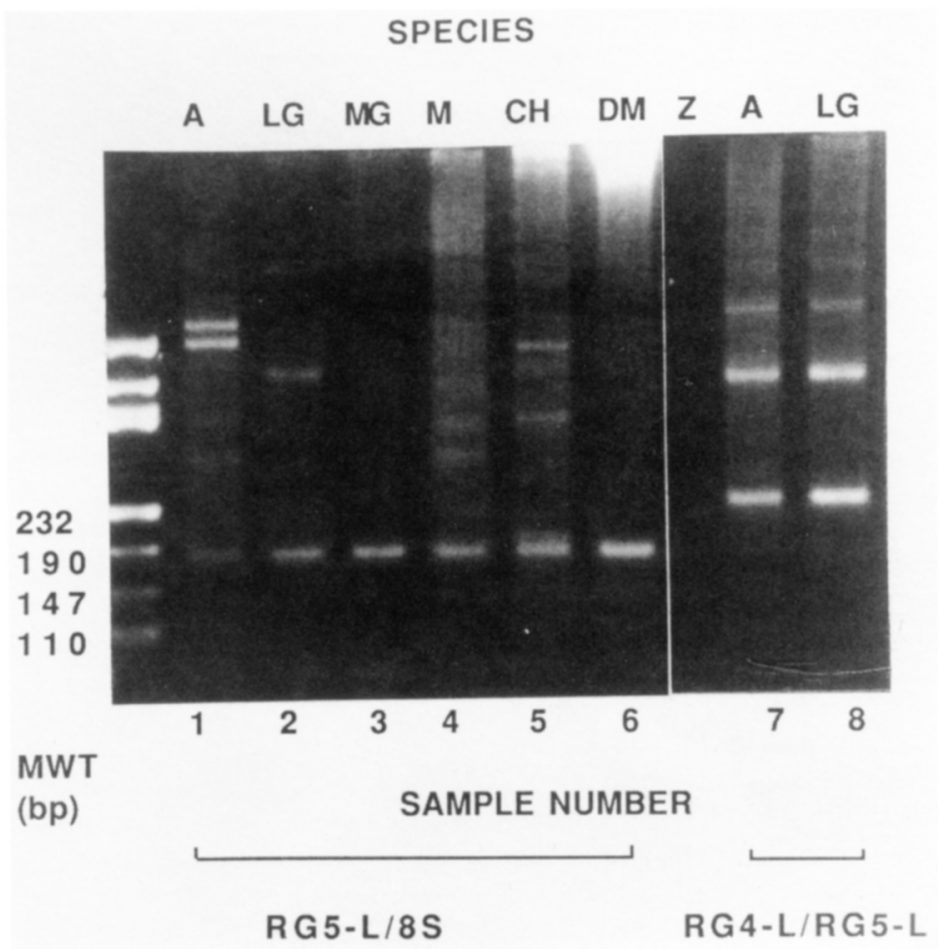

FIGURE 1 PCR-amplified DNA from species with either CSD or TSD. NuSieve 3:1 gel (4\%) (FMC, 1990), showing PCR-amplified products from genomic DNA: (Lane $A$ ) American alligator; (lane $L G$ ) leopard gecko; (lane $M G$ ) Mediterranean gecko; (lane $M$ ) mouse; (lane $C H$ ) chicken; (lane $D M)$ Drosophila melanogaster; (lane $Z$ ) zero control (no DNA). Samples 1-6 were amplified using primers RG5-L/8S and samples 7 and 8 were amplified using the primer pair RG4-L/RG5-L.

$\mathrm{X}-100,200 \mathrm{~m}$ each dNTP, 20 pmoles each primer (gel purified), 4.5 units of Taq polymerase (Promega), and $0.5-1.0 \mu \mathrm{g}$ of genomic DNA. The thermal profile for each reaction was: $94^{\circ} \mathrm{C}$ for $2 \mathrm{~min}$, followed by 35 cycles of annealing at $55^{\circ} \mathrm{C}$ for $1 \mathrm{~min}$, extending at $72^{\circ} \mathrm{C}$ for $1 \mathrm{~min}$ and denaturing at $94^{\circ} \mathrm{C}$ for $45 \mathrm{sec}$, followed by a final extension at $72^{\circ} \mathrm{C}$ for 5 min (using a TECHE PHC2). For the primer pair, 8S/RG5-L annealing was performed at $60^{\circ} \mathrm{C}$.

Several PCR reactions of each DNA were pooled for cloning. Amplified

TABLE 1 Percentage Conservation of a 38-Amino-acid Stretch from Within the SRY-box, Identified for Species with Either CSD or TSD

\begin{tabular}{|c|c|c|c|c|c|c|c|c|c|c|c|c|}
\hline & AES & AMA & LG & MG & $\mathrm{DM}$ & $\mathrm{CH}$ & SOX-4 & SOX-3 & SOX-2 & SOX-1 & $\mathrm{m}-\mathrm{y}$ & h-y \\
\hline ADW & $79-84$ & $58-66$ & $71-89$ & $84-95$ & $58-68$ & $66-71$ & $84-87$ & $63-66$ & 66 & $61-63$ & 53 & $45-47$ \\
\hline AES & & $63-68$ & $63-79$ & $76-82$ & $66-71$ & $61-71$ & $92-95$ & 68 & 71 & 66 & 55 & $45-47$ \\
\hline AMA & & & $45-61$ & $61-66$ & $79-95$ & 89-97 & $58-66$ & $87-95$ & $89-95$ & 89-95 & $60-63$ & 63 \\
\hline LG & & & & $66-87$ & $61-68$ & $47-63$ & $60-76$ & $53-63$ & $53-66$ & $47-51$ & $47-51$ & $42-53$ \\
\hline MG & & & & & $61-68$ & $55-66$ & $74-79$ & $63-66$ & $66-68$ & $53-63$ & $50-53$ & 45 \\
\hline $\mathrm{DM}$ & & & & & & 79-97 & $63-68$ & $87-95$ & $84-95$ & 84-92 & $58-66$ & $50-55$ \\
\hline $\mathrm{CH}$ & & & & & & & $66-71$ & $92-97$ & $89-95$ & 89-92 & $58-71$ & $68-71$ \\
\hline SOX-4 & & & & & & & & 66 & 66 & 61 & 55 & 50 \\
\hline SOX-3 & & & & & & & & & 95 & 97 & 58 & 61 \\
\hline SOX-2 & & & & & & & & & & 95 & 63 & 61 \\
\hline SOX-1 & & & & & & & & & & & 63 & 58 \\
\hline $\mathrm{m}-\mathrm{y}$ & & & & & & & & & & & & 76 \\
\hline
\end{tabular}

The conservative amino acid substitutions (Ser/Thr, Glu/Asp, Ile/Val/Leu) were considered homologous. ${ }^{25}$ Clones with incomplete sequence data in this region have not been included in the calculations. Maximum and minimum homologies have been quoted for comparison between groups of clones. 
bands were purified, blunted, and concatamerized. ${ }^{(18,21)}$ Resultant concatamers were linearized and cloned into either Bluescript (RG4-L/RG5-L) or pUC 18 (8S/RG5-L) vectors. Recombinant clones were identified by blue/white color selection (X-Gal/IPTG), or by colony screening, using radiolabeled primers. Clones were subsequently sequenced in both directions.

\section{RESULTS}

PCR methodology facilitated the rapid cloning of 17 American alligator (A), 2 leopard gecko (LG), 3 Mediterranean gecko (MG), 12 Drosophila melanogaster (DM), and 18 chicken (CH) $S R Y$-related sequences. Using the primer pair RG4-L/ RG5-L, a fragment of 228 bp was found in A, LG, and MG species that comigrated with an amplified mouse band (Fig. 1). Sequences containing the MAQ/ LEN motif, found in the autosomal mouse $S r y$-related genes, were not identified using these primers. To facilitate the cloning of these specific sequences, the primer $8 \mathrm{~S}$ was designed and tested for some species (A, DM, and $\mathrm{CH}$ ) giving a fragment of 174 bp (Fig. 1).

Various estimations of the fidelity of Taq DNA polymerase have been made. ${ }^{(22,23)}$ For the nucleotide and magnesium concentrations used for these experiments, we can assume a maximum cumulative error frequency of $10^{-5}$ (i.e., one wrong nucleotide per fragment or possibly only one wrong nucleotide per 10 fragments).

DNA sequences isolated from the species used in this study show stronger homologies to mouse autosomal $S r y$-related genes than to the human or mouse Y-specific loci (Table 1). The alligator sequences constitute three major protein classes and have been designated ADW, AES, and AMA, where the second and third letters denote amino acids that have been conserved specifically within the $S R Y$-box at positions 23 and 25 (ADW and AES) or 21 and 22 (AMA) of the 72 amino acids shown (Fig. 2). The ADW and AES groups have greatest similarity with Sox-4 (84-87\% and 92-95\%, respectively), whereas the AMA sequences show the highest degree of homology with Sox-1, Sox-2, and Sox-3 (87-95\%) (Fig. 2; Table 1). The levels of amino acid conservation between specific alligator and mouse $S R Y$-related sequences are greater than, or equivalent to, the level

\begin{tabular}{|c|c|c|c|c|c|}
\hline $\begin{array}{l}\mathrm{ma}-4 \\
\mathrm{ma}-3 \\
\mathrm{ma}-2 \\
\mathrm{ma}-1\end{array}$ & $\begin{array}{l}\text { HN } \\
-- \\
-- \\
--\end{array}$ & $\begin{array}{l}\text { AEISKRLGKR } \\
\text { S----- AD } \\
\text { S-------AE } \\
\text { S------ AE }\end{array}$ & $\begin{array}{l}\text { WKLLKDSDKI } \\
----T-A E-R \\
----S E T E-R \\
-- \text { VMSEAE-R }\end{array}$ & $\begin{array}{l}\text { PFIQEAERLR } \\
---D--K--- \\
---D--K--- \\
---D--K---\end{array}$ & $\begin{array}{l}\text { LKHMAD } \\
\text { AV--KE } \\
\text { AL--KE } \\
\text { AL--KE }\end{array}$ \\
\hline $\begin{array}{l}\text { sox } 5 \\
\text { xsox } 5 \\
h \text { sox } 5\end{array}$ & $\begin{array}{l}-- \\
--\end{array}$ & $\begin{array}{l}\text { SN---I--S- } \\
\text { SN---I--S- } \\
\text { SN---I--S- }\end{array}$ & $\begin{array}{l}\text {--AMTNLE-Q } \\
\text {--SMTNLE-- } \\
\text {--AMTNLE-Q }\end{array}$ & $\begin{array}{l}-Y Y E-Q A--S \\
-Y Y E-Q A--S \\
-Y Y E-Q A--S\end{array}$ & $\begin{array}{l}\text { KQ-LEK } \\
\text { KQ-IEK } \\
\text { KQ-LEK }\end{array}$ \\
\hline $\begin{array}{l}\text { sox6 } \\
\text { hsox6 }\end{array}$ & $\begin{array}{l}-- \\
--\end{array}$ & $\begin{array}{l}\text { SN---I--S- } \\
\text { SN---I--S- }\end{array}$ & $\begin{array}{l}\text {--SMSNQE-Q } \\
--S M S N Q E-Q\end{array}$ & $\begin{array}{l}-Y Y E-Q A--S \\
-Y Y E-Q A--S\end{array}$ & $\begin{array}{l}\text { KI-LEK } \\
\text { KI-IEK }\end{array}$ \\
\hline $\begin{array}{ll}\text { sox } 7 \\
\text { sox } 8 \\
\text { sox } 9 \\
\text { sox } 10\end{array}$ & $\begin{array}{l}-- \\
-- \\
-- \\
--\end{array}$ & $\begin{array}{l}--L-M---S \\
-V L--M---A \\
S------A E \\
S-------A E\end{array}$ & $\begin{array}{l}--A-T L-Q-R \\
--E-N A A E-R \\
----T-A E-R \\
----T E S E-R\end{array}$ & $\begin{array}{l}-Y V D----- \\
--V E-A--- \\
--D--K-- \\
--D--K---\end{array}$ & $\begin{array}{l}-Q--Q- \\
\text { VQ-LR- } \\
\text { AV--K- } \\
\text { AM--KE }\end{array}$ \\
\hline
\end{tabular}

$\begin{array}{llllll}m-y & Q- & T---O--C- & --S-T E A E-R & --\mathbf{E}---Q--K & \text { IL-RER } \\ h-y & \text { R- } & \text { S----Q--YQ } & --M-T E A E-W & --\mathbf{F}---Q K-Q & \text { AM-RER }\end{array}$

\begin{tabular}{|c|c|c|c|c|}
\hline $\begin{array}{l}A D W-2 \\
A D W-4 \\
A D W-5\end{array}$ & $\begin{array}{l}-- \\
--\end{array}$ & 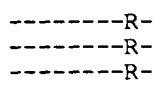 & $\begin{array}{l}-Q-Q--E-- \\
-Q-Q--E-- \\
-Q--Q--E--\end{array}$ & $\begin{array}{l}--V G K----- \\
--V K--D G L L \\
--V K--G G--\end{array}$ \\
\hline $\begin{array}{l}\text { AES-1 } \\
\text { AES }-2 \\
\text { AES }-4\end{array}$ & $\begin{array}{l}-- \\
--\end{array}$ & - & 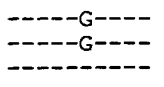 & $\begin{array}{l}---\mathrm{R}--- \\
---\mathrm{R}---- \\
---\mathrm{RA}---\end{array}$ \\
\hline $\begin{array}{l}\text { AMA1 } \\
\text { AMA2 }\end{array}$ & -- & $\begin{array}{l}S V-----A E \\
S-----A E\end{array}$ & $\begin{array}{l}--- \text { SEAE-R } \\
-\cdots-S E A E-R\end{array}$ & $\begin{array}{l}--\mathrm{SD}--\mathrm{K}--- \\
---\mathrm{D}--\mathrm{K}---\end{array}$ \\
\hline
\end{tabular}

AMA2
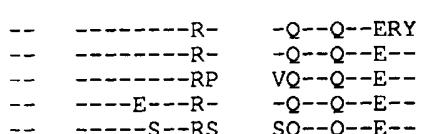

$\mathrm{LSRRR} * \mathrm{SV}-$

$--V K-\star S V-$

$--\mathrm{VK}--\mathrm{G}---$

$--\mathrm{VK}--\mathrm{G}-\mathrm{-}$

$---\cdots$

$\mathrm{V}-\mathrm{-n-}$

$-\cdots--$

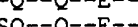

$--\mathrm{VK}--\mathrm{G}---$

- - - -

\begin{tabular}{|c|c|c|c|c|c|}
\hline D10 & -- & $S------A E$ & $----A--E-R$ & $---\mathrm{D}--\mathrm{K}---$ & $A L--K E$ \\
\hline D16 & -- & $\mathrm{P}--\cdots \cdots$ & $----S E A E-R$ & $-\mathrm{Y}-\mathrm{D}--\mathrm{K}---$ & $A Q--K E$ \\
\hline D17 & -- & $S------A E$ & --- SEAE-R & $-Y-D--K---$ & $A Q--K E$ \\
\hline 23 & -- & $S-------A E$ & $----A E-E-R$ & $---\mathrm{D}--\mathrm{K}---$ & $A L--K A$ \\
\hline 33 & -- & $S-------A E$ & $\cdots-A E-E-R$ & $-\mathrm{L}-\mathrm{D}--\mathrm{K}---$ & $\mathrm{AL}--\mathrm{NH}$ \\
\hline 36 & Q- & $\mathrm{SH}-\longrightarrow--\mathrm{AE}$ & $\cdots-A A-E-R$ & $---\mathrm{D}--\mathrm{K}---$ & $A L--K E$ \\
\hline 53 & -- & $S-------A E$ & $---A E-E-R$ & $---\mathrm{D}--\mathrm{K}---$ & $A L--K E$ \\
\hline 54 & -- & $S------A E$ & $--D-S E-E-R$ & $---\mathrm{D}--\mathrm{K}---$ & $V--K E$ \\
\hline-4 & -- & $S-------A E$ & --- SEAE-R & $---D D S-$ & $A M--K E$ \\
\hline$H-7$ & -- & $S-S----A E$ & $---S E A E-R$ & $---D--K---$ & $\mathrm{AM}--\mathrm{KE}$ \\
\hline$H-46$ & -- & $S------A E$ & $---S E A E-R$ & $---D--K---$ & $A M--K E$ \\
\hline$i-1$ & -- & $S------A E$ & $--Q-S E A E-R$ & $--\mathrm{D}--\mathrm{K}-\mathrm{H}-$ & $A M--K E$ \\
\hline $\mathrm{CH}-61$ & -- & $S------A E$ & $---S E A E-R$ & $---D--K-P-$ & $A M--K E$ \\
\hline $\mathrm{CH}-60$ & -- & $S------A E$ & $---S E A E-R$ & $-Y-D--K---$ & $A Q--K E$ \\
\hline 1$]-32$ & -- & $S---Q---A E$ & $---S E A E-R$ & $-Y-D--K---$ & $A Q^{-}-K E$ \\
\hline$H-44$ & -- & $S------A E$ & --- SEAE-R & $-Y-D--K--$ & $A Q--K E$ \\
\hline$H-2$ & -- & $S-M-----A E$ & $---S E A E-R$ & $---D--K--$ & AS- -KE \\
\hline $\mathrm{H}-3$ & -- & $S-------\mathrm{AD}$ & $--S-A E-R$ & $---D--K---$ & $A V--K E$ \\
\hline
\end{tabular}

FIGURE 2 Comparison of $S R Y$ and related amino acid sequences for seven species, representing 38 of the 80 amino acids constituting the $S R Y$-box region of the $S R Y$ genes. Regions containing PCR primer sequence have not been considered when calculating homologies (see Table 1). Species are: American alligator (A), leopard gecko (LG), Mediterranean gecko (MG), Drosophila melanogaster (DM), and chicken (CH). Using the primer pair RG5-L/8S AMA, DM, and CH sequences were amplified; ADW, AES, LG, and MG sequences were amplified with primers RG4-L/RG5-L. These sequences include 38 of 80 amino acids that constitute the mammalian $S R Y$-box region of $S r y$ and $S R Y$-related genes. Where one or more of the clones sequenced for any species were identical to each other, only one has been shown. Each amino acid sequence was compared against the sex-specific copies of $S R Y$ (m-y/mouse, h-y/human) and $S r y$-related mouse autosomal genes sox-1 to 4 . Dashed lines (-) represent sequence identity with respect to sox-4. Amino acids outlined for h-y and $\mathrm{m}$-y indicate sex-specific motifs. An asterisk is inserted in LG sequences for alignment. GenBank accession numbers for sequences listed are M86310 M86339 inclusive. 
of homology found among the different mouse (Sox-1, Sox-2, Sox-3, and Sox-4; 6197\%) and alligator (ADW, AES, and AMA; 58-84\%) protein classes (Table 1). The conserved sequence homology observed between alligator and mouse sequences for this region of the $S R Y$-box may reflect functional conservation, suggesting that these proteins have similar roles in reptiles and mammals.

For sequences differing in only one amino acid, e.g., AES-1 and AES-2, $\mathrm{CH}-7$ and $\mathrm{CH}-46, \mathrm{CH}-32$ and $\mathrm{CH}-44$, nucleotide sequences varied by a single base of the amino acid codon. This may suggest that these clones are identical and that the difference observed is a consequence of polymerase infidelity.

A comparison of $S R Y$-related sequences derived from other species (Fig. 2) shows that both LG and MG SRY-box sequences share the conserved amino acid region of $\mathrm{ADW}$, while the $\mathrm{DM}$ and $\mathrm{CH}$ sequences are more closely related to the AMA group (Fig. 2; Table 1). The degree of $S R Y$-box homology between species with temperature-dependent sex determination (e.g., ADW and LG; $71-89 \%$ ), or species with chromosomal sex determination (e.g., $\mathrm{DM}$ and $\mathrm{CH}$; 79$97 \%$ ), is not significantly different from the level of amino acid conservation among species with alternative modes of sex determination (e.g., $\mathrm{ADW}$ and $\mathrm{MG}$, 84-95\%; AMA and DM, 79-95\%; AMA and $\mathrm{CH}, 89-97 \%$; Table 1).

Preliminary work in our laboratory, using the PCR-amplified sequences as probes, has identified a large number of different $S R Y$-box-containing cDNAs from alligator and chicken embryonic cDNA libraries (unpublished results). These findings suggest that PCR-derived sequences represent genes that are developmentally expressed and that the large number of these closely related sequences is not due to PCR artifacts.

Different primer pairs have been used to amplify selectively different groups of $S R Y$-box sequences, revealing highly conserved sequences in invertebrates $(D$. melanogaster) and a number of vertebrates (reptiles and birds). None of the sequences isolated so far show sequence characteristics unique to $S R Y / S r y$, but the size of this growing gene family suggests that such sequences have yet to be discovered.

The use of PCR to identify members of this gene family has provided the first step for assessing the significance and degree of evolutionary conservation of these highly related genes.

\section{DISCUSSION}

Mammalian Y-specific $S R Y$ and autosomal $S R Y$-related gene sequences contain a highly conserved $S R Y$-box motif. ${ }^{(5,14)}$ The distinction between these $S R Y$-box sequences is the invariant site specificity of critical amino acids in the putative $S R Y$ gene product. ${ }^{(2,3)}$ The SRY-box domains discovered for other species ${ }^{(19)}$ (Fig. 2) show greater homology with the mouse Sox genes than with the male-specific SRY (Table 1). These preliminary data suggest that $S r y / S R Y$ may act as a major testis-determining gene only in mammals, although it is possible that we failed to amplify sex-specific $S R Y$ sequences in the species examined. The high degree of conservation among $S R Y$ box sequences presents difficulties when assessing their evolutionary relationships to $S r y / S R Y$. Adequate comparison requires sequence information from outside the $S R Y$-box motifs.

Mouse autosomal copies of Sry have been shown to be expressed predominantly in neural tissue and in other ectoderm derivatives of the developing mouse embryo. ${ }^{(20)}$ The strong homology that exists between the $S R Y$-box of mouse autosomal Sry-related genes and $S R Y$-related genes of other species (Table 1) suggests that their functions may be similar. It is reasonable to suggest that the alligator $S R Y$-related gene products do act as transcriptional regulators in view of the putative DNA-binding domain they share with a number of known transcription factors. For other families of transcription factors, e.g., homeobox genes, paired box genes, and zinc finger genes, ${ }^{(24)}$ the conservation of DNA-binding domains has been shown to reflect functional homology for the resulting gene products. Further analyses, including developmental expression and cellular localization studies (using cDNA sequences derived from the American alligator and chicken), will help to define the role of $S R Y$-related genes in vertebrate development.

\section{ACKNOWLEDGMENTS}

Professor Mark W.J. Ferguson's assistance with the collection of Alligator mississippiensis embryos is gratefully acknowledged. We thank Ted Joanen and associated staff of the Rockefeller Wildlife Refuge, Louisiana Department of Wildlife and Fisheries, for the collection and transportation of Alligator mississippiensis eggs. Collaboration offered by Richard Griffiths is particularly appreciated. Jane Hodgkinson provided valuable assistance with plasmid preparations and DNA sequencing. This work was supported by grants from The Wellcome Trust, SERC, and DFG.

\section{REFERENCES}

1. Koopman, P., A. Munsterberg, B. Capel, N. Vivian, and R. Lovell-Badge. 1990. Expression of a candidate sex determining gene during mouse testis differentiation. Nature 348: 150-152.

2. Berta, P., J.R. Hawkins, A.H. Sinclair, A. Taylor, B. Griffiths, P.N. Goodfellow, and M. Fellous. 1990. Genetic evidence equating $S R Y$ and the testis determining factor. Nature 348: 448-450.

3. Jager, R.J., M. Anvret, K. Hall, and G. Scherer. 1990. A human XY female with a frameshift mutation in $S R Y-$ A candidate testis determining factor. Nature 348: 452-454.

4. Koopman, P., J. Gubbay, N. Vivian, P.N. Goodfellow, and R. Lovell-Badge. 1991. Male development of chromosomally female mice transgenic for Sry. Nature 351: $117-121$.

5. Sinclair, A.H., P. Berta, M.S. Palmer, J.R. Hawkins, B.L. Griffiths, M.J. Smith, J.W. Foster, A.M. Frischauf, R. Lovell-Badge, and P.N. Goodfellow. 1990. A gene from the human sex determining region encodes a protein with homology to a conserved DNA binding motif. Nature 346: $240-244$.

6. Ner, S.S. 1992. HMG's everywhere. Curr. Biol. 2: 208-210.

7. Kelly, M., J. Burke, M. Smith, A. Klar, and D. Beach 1988. Four mating type genes control sexual differentiation in fission yeast. EMBO J. 7: 1537-1547.

8. Staben, C. and C. Yanofsky. 1990. Neurospora crassa a mating type region. Proc. Natl. Acad. Sci. 87: 4917-4921.

9. Sugimoto, A., Y. Jino, Y. Watanabe, and M. Yamamoto. 1991. Schizosaccharomyces pombe ste $11^{+}$encodes a transcription factor with an HMG motif that is a critical regulator of sexual development. Genes \& Dev. 5: 1990-1999.

10. Waterman, M.L., W.H. Fischer, and K. Jones. 1991. A thymus-specific member of the HMG protein family regulates the $T$ cell receptor Ca enhancer. Genes \& Dev. 5: 656-669.

11. Giese, K., A. Amsterdam, and R. Grosschedl. 1991. DNA-binding properties of the HMG domain of the lymphoid-spe- 
cific transcriptional regulator LEF-1. Genes \& Dev. 5: 2567-2578.

12. Jantzen, H.M., A. Admon, S.P. Bell, and R. Tjian. 1990. Nucleolar transcription factor hUBF contains a DNA binding motif with homology to HMG proteins. Nature 344: 830-836.

13. Nasrin, N., C. Buggs, X.F. Kong, J. Carnaza, M. Goebl, and M. AlexanderBridges. 1991. DNA-binding properties of the product of the testis-determining gene and a related product. Nature 354: $317-320$.

14. Gubbay, J., J. Collignon, P. Koopman, B. Capel, A. Economou, A. Munsterberg, N. Vivian, P.N. Goodfellow, and R. LovellBadge. 1990. A gene mapping to the sex determining region of the mouse $\mathrm{Y}$ chromosome is a member of a novel family of embryonically expressed genes. Nature 346: $240-250$.

15. Bianchi, M.E., L. Falciola, S. Ferrari, and M.J. Lilley. 1992. The DNA binding site of HMG1 protein is composed of two similar segments (HMG boxes), both of which have counterparts in other eukaryotic regulatory proteins. EMBO J. 11: 1055-1063.

16. Harley, V.R., D.I. Jackson, P.J. Hextall, J.R. Hawkins, G.D. Berkowitz, S. Sockanathan, R. Lovell-Badge, and P.N. Goodfellow. 1992. DNA binding activity of recombinant SRY from normal males and XY females. Science 255: 453-456.

17. Sambrook, J., E.F. Fritsch, and T. Maniatis. 1989. Molecular cloning: A laboratory manual, 2nd ed., pp. 9.16-9.19. Cold Spring Harbor Laboratory Press, Cold Spring Harbor, New York.

18. Kunkel, L.M., K.D. Smith, S.H. Boyer, D.S. Borgaonkar, S.S. Watchel, O.J. Miller, W.R. Breg, H.W. Jones, and J.M. Rary. 1977. Analysis of human Y-chromosome specific reiterated DNA in chromosome variants. Proc. Natl. Acad. Sci. 74: 12451249.

19. Griffiths, R. 1991. The isolation of conserved DNA sequences related to the human sex-determining region $Y$ gene from the lesser black-backed gull (Larus fuscus). Proc. R. Soc. Lond. B 244: 123-128.

20. Collignon, J., personal communication.

21. Jung, V., S.B. Pestka, and S. Pestka. 1990. Efficient cloning of PCR generated DNA containing terminal restriction endonuclease recognition sites. Nucleic Acids Res. 18: 6156.

22. Saiki, R.K., D.H. Gelfand, S. Stoffel, S.J. Scharf, R. Higuchi, G.T. Horn, K.B. Mullis, and H.A. Erlich. 1988. Primer-directed enzymatic amplification of DNA with a thermostable DNA polymerase. Science 239: 487-491.

23. Fucharoen, S., G. Fucharoen, P. Fucharoen, and Y. Fukumaki. 1989. A novel ochre mutation in the $\beta$-thalassemia gene of a Thai. J. Biol. Chem. 264: 7780.

24. Dressler, G.R. and P. Gruss. 1988. Do multigene families regulate vertebrate development? Trends Genet. 4: 214-219.

25. Scott, M.P., J.W. Tamkun, and G.W. Hartzell III. 1989. The structure and function of the homeodomain. Biochim. Biophys. Acta 989: 25-48.

Received September 9, 1992; accepted in revised form December 1, 1992. 


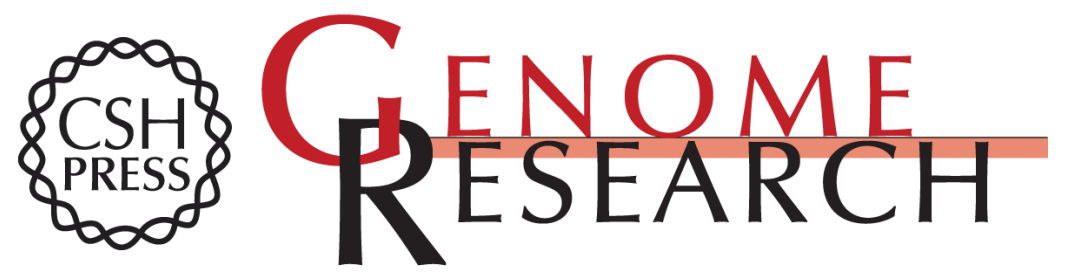

\section{PCR amplification of SRY-related gene sequences reveals evolutionary conservation of the SRY-box motif.}

A M Coriat, U Müller, J L Harry, et al.

Genome Res. 1993 2: 218-222

Access the most recent version at doi:10.1101/gr.2.3.218

References This article cites 23 articles, 8 of which can be accessed free at:

http://genome.cshlp.org/content/2/3/218.full.html\#ref-list-1

\section{License}

Email Alerting Receive free email alerts when new articles cite this article - sign up in the box at the Service top right corner of the article or click here.

\section{Affordable, Accurate Sequencing.}

To subscribe to Genome Research go to:

https://genome.cshlp.org/subscriptions 